\title{
Underestimation of Social Danger of Deception in the Russian Criminal Law
}

\author{
Vladislav F. Shchepelkov* \\ Saint-Petersburg State University \\ 7-9 University Embankment, Saint-Petersburg, 199034, Russia
}

Received 19.07.2015, received in revised form 18.08.2015, accepted 02.09.2015

\begin{abstract}
The article examines a problem of adequacy of reflection in the current Russian criminal law of social danger of actions involving misleading of victims.

The author concludes that the Russian Criminal Code undervalues the social danger of fraudulent acts, including various types of deception: criminologically unjustified exclusion of deception as a possible way to commit some crimes, which violates the principles of the criminalization of acts, differentiation and individualization of criminal responsibility; the presence in the Criminal Code of the Russian Federation of independent element of deception (falsification) does not solve the problem of the criminal-law protection of the interests, the means of violation of which is deception; legislative practice of the increase of responsibility for the additional socially dangerous consequences that inevitably or highly likely occur as a result of fraudulent activities should be considered as valid. During its implementation it is advisable to consider the inclusion of a sign of the occurrence of serious consequences as qualifying, as is done in respect of the offenses referred to in Art.285, 286 of the Criminal Code of the Russian Federation.
\end{abstract}

Keywords: criminal liability, deception, falsification, criminal law.

DOI: 10.17516/1997-1370-2015-8-10-2107-2115.

Research area: law.

Deception is not an uncommon phenomenon, if not typical. A modern man deals with it every day, at the household level and in the profession, politics, economy and media.

Deception can be "selective" when one or more selected people are misled. But often the masses of people are being deceived, for example, in the sale of counterfeit goods, in the publication of distorted facts, etc. Thus, according to the WHO estimates, approximately $10 \%$ (or about 21 billion dollars) of the worldwide turnover in the pharmaceutical industry is based on the sale of counterfeit drugs (Department of Essential Drugs and Other Medicines. Guidelines for the Development of Measures to Combat Counterfeit Drugs. Geneva, Switzerland: World Health Organization; 1999. WHO/EDM/QSM/99.1.) ${ }^{1}$. Interesting information is given on scientific deception. $42 \%$ of scientists questioned by $\mathrm{M}$. Mahoney said that they had dealt with fake data in their research practice, at this, biologists (57\%) more often than the representatives of human

(C) Siberian Federal University. All rights reserved

* Corresponding author E-mail address: volga0@yandex.ru 
sciences - psychologists (41\%) and sociologists $(38 \%)^{2}$.

The attitude to deception in society is negative in most cases ${ }^{3}$. This is particularly evident at the individual level. Thus, deception from close people is very painful for people. Often, hypocrisy is among the acts that are forgiven with difficulty, and sometimes, people cannot forgive deception at all, if it is associated with treachery, betrayal (in friendship, family). Deception from close people often causes severe soul wounds, leads to rupture of close relationships, serious crimes. Examples of this are countless.

However, in the framework of this article we are interested in the estimation of the social danger of deception (various types of falsification) in order to develop technical and legal algorithms to construct the criminal law standards.

1. In the theory of the criminal law, deception is often regarded as one of the possible ways to commit a crime, which is quite explainable. After all, deception is rarely an end in itself; it is often a means to achieve certain goals that may be diverse (greed, revenge, promotion in career, selfassertion, prevention of adverse effects, etc.).

In the doctrine of the criminal law the method of crime received significant attention. It was considered in the works devoted to the objective aspect of crime ${ }^{4}$, elements of certain crimes and was the subject of a separate study ${ }^{5}$.

Deception as a phenomenon in the criminal law doctrine was not exposed to special studies at the level of the General Part, the theory of construction of the criminal law standards. At the same time, deception was studied in great detail as a method to commit groups of crimes ${ }^{6}$, certain crimes; first of all, we are talking about fraud, which is a subject of many scientific works ${ }^{7}$. For this crime the Supreme Court of the Russian Federation defined a concept of deception highlighting its two varieties: active and passive deception. In paragraph 2 of the
Resolution of the Plenum of the Supreme Court of the Russian Federation dated December 27, 2007 No. 51 "On judicial practice in cases of fraud and embezzlement" it is provided that "deception as a way to commit theft or acquisition of a right of property of another, responsibility for which is provided for by the Article 159 of the Criminal Code of the Russian Federation, may consist in the conscious representation of false, untrue information or in non-disclosure of true facts, or in deliberate actions (for example, provision of counterfeit goods or other subjects of transaction; using a variety of deceptive practices in payments for goods or services or when gambling, in imitation of cash settlements, etc.) aimed at misleading of the property owner or other person".

2. Deception as a method of committing a crime or its varieties are mentioned in the criminal law relatively frequently: obstruction of realization of electoral rights or the work of election commission (p. "a", p. 2, Art.141 of the Criminal Code of the Russian Federation), involvement of a minor to commit a crime (Art.150 of the RF Criminal Code), fraud (Art.159 of the RF Criminal Code) and its variants (Art.159.1-159.6 of the RF Criminal Code), causing damage to property by deception or abuse of trust (Art.165 of the RF Criminal Code), illegal use of documents for formation (foundation, reorganization) of the legal entity (Art.2, Art.173.2 of the RF Criminal Code), illegal receipt of a credit (Art.176 of the RF Criminal Code), illegal obtaining of information constituting a state secret (Art.283.1 of the RF Criminal Code), evasion of military service by simulating illness or otherwise (Art.339 of the RF Criminal Code), etc. In these cases, it is an element-making circumstance.

Inclusion in the structure of the element of a crime of deception as a method is formally and substantively justified. Formally, the method can separate the criminal from the non-criminal (for 
example, in a situation with tax evasion), one element from the other (various forms of theft). In terms of content, the method often characterizes social danger of the offense (nature, extent). Depending on which method was used, the legislator differentiates responsibility and uses structures allowing its individualization.

Concretization of the method of crime in the construction of the criminal law standards implies that the responsibility for a particular crime can come only when it was committed by a method stated in the law. In this regard, the task of the legislator is to specify in the law all the methods, in the use of which the deeds form signs of a socially dangerous act. Often, the legislator does not indicate the method of crime at all, which implies recognition of the deed as a wrongful criminal act, regardless of the method of its commission.

It is known that deception can be used to commit many socially dangerous acts. In two cases the legislator recognizes such deeds as criminal: 1) when deception is mentioned in the law as a method of crime; 2) when a method of crime is not concretized. If the legislator called criminal methods, but none of them is deception, then the commission of the deed by deception does not constitute an independent crime.

Thus, Art.279 of the RF Criminal Code provides for liability for armed rebellion (organization of armed rebellion or active participation in it to overthrow or forcibly change the constitutional order of the Russian Federation or violate the territorial integrity of the Russian Federation). This offense is classified as extremely serious; the maximum possible penalty is twenty years in prison and restriction of liberty for a term of two years. In fact, here it refers to the violent seizure of power by armed force.

At the same time, the power can also be seized by various kinds of falsification. For example, Zorin A.V. highlights a political fraud, one of the commission methods of which is deception ${ }^{8}$. However, deception is not provided for as a method of crime in the Art.279 of the RF Criminal Code. Criminal liability for the seizure of power can occur only in the presence of a violent armed method. A political fraudster will be responsible for other crimes.

If there is a political fraud when the offender earns mandate of power by rigging elections, the liability is incurred for offenses against citizens' electoral rights. Art.142.1 of the RF Criminal Code (Falsification of voting results) provides for liability for the inclusion of unrecorded ballots in the number of ballots used when voting, or providing false information about voters, referendum participants, or deliberately wrong listing of voters, referendum participants reflected in the inclusion of persons who do not have the right to vote, the right to participate in referendum, or fictitious persons, or falsification of signatures of voters, referendum participants in the lists of voters, referendum participants, or substitution of valid ballots with marks of voters, referendum participants, or deterioration of ballots resulting in the inability to determine the will of voters, referendum participants, or illegal destruction of ballots, or knowingly incorrect counting of votes of voters, referendum participants, or the signing by the members of the election commission, referendum commission of the protocol on the voting results before the vote counting or determination of voting results, or deliberately wrong (inconsistent with real voting results) compilation of a protocol on the voting results, or illegal making changes in the protocol of voting results after its completion, or deliberately wrong determination of results of election, referendum.

The most severe possible punishment provided for falsification of the voting results is four years in prison, a crime attributed to medium-gravity crimes. 
It is unlikely that the difference in methods of committing a socially dangerous act changes its social danger so much that it differentiates the criminal liability (in case of deception the strictest punishment is 4 years of imprisonment, if by the armed way - twenty years of imprisonment and 2 years of restriction of liberty). After all, the main danger of the seizure of power is in the seizure of power itself.

In connection with this we can make a conclusion about the underestimation of deception as a possible method for the seizure of power. It is due to the fact that Art.279 of the RF Criminal Code does not mention deception as a method of commission of crime.

Constructive exception of deception as a possible method of commission of crime should be criminologically justified and comply with the principles of criminalization of acts, differentiation and individualization of criminal responsibility.

3. Elements of certain crimes can be deception themselves. These include elements of various kinds of "falsification" ("forgery"): falsification of electoral documents, referendum documents (Art.142 of the RF Criminal Code), falsification of election results (Art.142.1 of the RF Criminal Code), falsification of the unified state register of legal entities, register of holders of securities or the depository accounting system (Art.170.1 of the RF Criminal Code), falsification of financial accounting documents and statements of financial organizations (Art.172.1 of the RF Criminal Code), forgery of state hallmark (Art.181 of the RF Criminal Code), abuse in the issuance of securities (Art.185 of the RF Criminal Code), the provision of deliberately incomplete or false information determined by the laws of the Russian Federation on securities (Art.185.1 of the RF Criminal Code), entry in the register of holders of securities of false information (P.3 of Art.185.2 of the RF Criminal Code), falsification of the decision of general meeting of shareholders (participants) of a commercial company or the decision of the Board of Directors (Supervisory Board) of a business entity (Art.185.5 of the RF Criminal Code), making of counterfeit money or securities (Art.186 of the RF Criminal Code), forgery by an official (Art.292 of the RF Criminal Code), falsification of evidence and the results of operative-search activity (Art.303 of the RF Criminal Code), forgery of documents (Art.327 of the RF CriminalCode), etc. And this list is regularly updated. Thus, the Federal Law dated December 31, 2014 No. 532-FZ included in the Russian Criminal Code the Article 238.1 (Circulation of counterfeit, substandard and unregistered medicines, medical products and trafficking of counterfeit biologically active supplements) that provides for liability for the manufacture, sale or importation into the territory of the Russian Federation of the counterfeit medicines or medical products, or sale or importation into the territory of the Russian Federation of substandard medicines or medical products, or illegal manufacture, sale or importation into the Russian Federation for the purpose of sale of unregistered medicines or medical products, or manufacture, sale or importation into the Russian Federation of counterfeit biologically active supplements containing pharmaceutical substances that were not declared during the state registration, in especially big amount.

Falsification, including formally producing signs of crimes, is a common phenomenon, even in such a sensitive area as justice. Thus, according to S.V. Astashov, in the procedure of consideration of claims of falsification of evidence (Art.161 of the RF APC) by arbitration courts, $57 \%$ to $65 \%$ of the disputed written evidences are recognized invalid (falsified) ${ }^{9}$.

The analysis of the considered elements shows that at their construction the law often takes on the shortcomings of two kinds. 
The first kind is connected with the fact that the construction of the element of falsification does not consider the goals, the rule reflects only a method of a socially dangerous act, the phenomenon itself, and its social danger does not receive an adequate legal assessment. Thus, in Art.185.5 of the RF Criminal Code provides for liability for falsification of the decision of the general meeting of shareholders (participants) of the business entity or the decision of the Board of Directors (Supervisory Board) of the business entity. The actions specified in this article, as a rule, are one of the methods of illegal seizure of an organization. This rule appeared in the RF Criminal Code in order to counter corporate takeovers. The construction of the rule says nothing about the goals of this falsification. The acts listed in this article are committed in order to primarily take over the control of the organization ${ }^{10}$. However, this circumstance, the availability of which depends substantially on the nature and degree of social danger of the act, is not taken into account by the legislator.

There is a socially dangerous act - taking over the control of the organization. There are typical methods for its implementation. A criminal-legal construction should take into account that falsification is only a method to achieve the goal. The main harm from seizure is the loss of control over the organization. And the current criminal law does not adequately protect from this. The offender shall be liable only for the falsification of documents. The RF Criminal Code does not have a special rule on liability for seizure of control ${ }^{11}$.

Hence, we come up with another conclusion. Inclusion in the law of an independent element of falsification (deception) does not solve the question of the criminal-law protection of interests, the method for violation of which is deception.
However, this does not mean that the law should not have independent elements of falsification. It is not possible to operate without them in a number of cases, because they help to protect the management relations. For example, the rule on forgery of documents (Art.327 of the RF Criminal Code) helps to protect the official circulation of documents regardless of which rights and duties the forged documents certifies. However, this rule does not adequately protect the relations that will be broken in case of using a forged document.

4. Falsification (deception) sometimes inevitably generates the risks of additional, more distant socially dangerous consequences. The use of counterfeit spare parts is often the cause of accidents and disasters ${ }^{12}$. Several accidents that occurred in 2008-2009 with the Mi-8 helicopters (in the Volgograd region, as well as abroad - in Kandahar and Liberia) were due to failure of the tail rotor blades when the reconstruction companies installed illicit blades, as well as expired engines and engines that did not match technical specifications for these types of helicopters. In total, 25 passengers and crew members died $^{13}$. Cases of criminal prosecution for the sale of counterfeit plane parts are quite common. ${ }^{14}$.

Fraud related to the sale of low-quality parts becomes the cause of road and air accidents. A higher degree of social danger of fraud connected with the sale of counterfeit parts, when there is a real threat to social safety, is reflected in the qualification of crimes. According to p. 9 of the Regulation of the Plenum of the Supreme Court of the Russian Federation dated December 27, 2007 No. 51 "On judicial practice in cases of fraud and embezzlement", if a person sells counterfeit goods by deceiving consumers about the quality and other characteristics of the goods affecting the cost, while these actions are related to the production, storage or transportation for the 
purpose of sale or to the sale of counterfeit goods that do not meet the requirements of safety of life or health of consumers, the actions constitute a set of crimes stipulated by the relevant parts of Art. 159 and 238 of the RF Criminal Code.

Sales of counterfeit drugs and their subsequent use in health care inevitably affect the effectiveness of treatment. At best, the patient does not get worse, and often a lack of proper treatment substantially impairs health of the patient. Fraud related to the sale of substances unsuitable for the treatment under the guise of medical products not only causes damage to property, but also poses a threat to public health. This fact cannot be ignored when assessing the social danger of the offense. That is why Art.238.1 of the RF Criminal Code was included in the Criminal Code of the Russian Federation. Now, fraud involving the sale of counterfeit medicines will be qualified not only by Art.159 of the RF Criminal Code, but also, if it is committed in the amount of more than 100 thousand roubles, by Art.238.1 of the RF Criminal Code $^{15}$. Prior to the inclusion of this provision in the RF Criminal Code the mentioned the consequences could be taken into account by the law enforcer at individualization of responsibility as a circumstance that characterizes the social danger of the offense under the sanction of the article on fraud ${ }^{16}$.

Another example of strengthening of responsibility for additional socially dangerous consequences arising as a result of fraudulent acts is inclusion in Art.159 of the RF Criminal Code of a special aggravating attribute (P. 4 fraud that resulted in the deprivation of a citizen's right to shelter). The legislator has thus taken into account the inevitable harm to the constitutional human right to housing if the subject of fraud is the housing.
The occurrence of other socially dangerous consequences as a result of falsification is due to either the presence of a special subject of fraud (as in the case of housing) or the specificity of the method of fraud, by means of which it is carried out (as in the case of the sale of counterfeit medicines and other goods (it also can be services), the use of which poses a threat to public safety). Another important observation - often, additional consequences are more dangerous than damage to property coming as a direct result of fraudulent deception.

Because of this, the legislative practice of increasing the responsibility for additional socially dangerous consequences, inevitably or highly likely occurring as a result of fraudulent activities, should be considered as justified. This can be done in two ways: either by the inclusion of aggravating circumstances, or by the establishment of certain rules.

Today, taking into account additional consequences of fraudulent acts at the level of elements of crime is done selectively, by separate objects. Serious consequences that were not taken into account in the elements of crime are taken into account by the law enforcer when sentencing as a circumstance that characterizes social danger of the offense (p. "b" of Art.63 of the RF Criminal Code). At the same time, it is advisable to consider the inclusion of a circumstance of the serious consequences resulting from fraud as the qualifying, differentiating responsibility, as is done in respect of the elements of offenses referred to in Art.285, 286 of the RF Criminal Code. This will help to take into account any serious consequences during classification. At the same time, this construction will not prevent further differentiation of responsibility, if required. 
Op. by Albert Wertheimer, Nicole Cheney, Thomas Santella. Counterfeit Pharmaceuticals: Current Status and Future Projections. Journal of the American Pharmaceutical Association 43 (6): 710-718, 2003. (http://www.provisor.com.ua/ archive/2005/N6/art_32.php - Accessed date 02/20/2015).

2 See: Falsification in science. Siberian skeptical observer paranormality. http://ssop.kspu.ru/falsifik.htm - Accessed date $02 / 20 / 2015$.

3 Deception is often justified when it promotes achieving socially useful purposes. Often, we do not judge a person who does not say to a close relative about a serious illness just not to aggravate the situation. Sometimes, in order to prevent panic people do not get the information on the possible adverse effects, etc.

4 See e.g.: Kudryavtsev V.N. Objective aspect of crime. M., 1960; Malinin V.B., Parfenov A.F. Objective aspect of crime. $\mathrm{SPb}$ : Publishing house of the Institute of Law (St. Petersburg). 2004.

5 See e.g.: Shilovsky S.V. Method of committing a crime as an indication of the criminal offense and differentiating means. PhD thesis on Legal Sciences. Arkhangelsk, 2014; Mikhailov N.F. Method of committing a crime and its criminal-legal value. $\mathrm{PhD}$ thesis on Legal Sciences. M., 2007; Yakubovich O.P. Method of committing a crime and its criminal-legal value. $\mathrm{PhD}$ thesis on Legal Sciences. M., 2004.

6 See: Tutukov A.Yu. Deception as a way of committing crimes in the sphere of economics: historical, legislative, theoretical and law-enforcement aspects. Abstract of the PhD thesis on Legal Sciences. Krasnodar, 2008. He allocated a group of crimes that have a common concept of "commercial fraud".

7 See e.g. Bondar A.V. Fraud as a form of criminal assault against property and features of its manifestation in the field of banking activities: Criminal-legal aspect: $\mathrm{PhD}$ thesis on Legal Sciences. Krasnoyarsk, 2003; Osokin R.B. Criminal-legal characteristics of methods of committing fraud: PhD thesis on Legal Sciences. M., 2004; Krasikova A.A. Acquisition of property of another and theft of property of another by fraud or abuse of trust: PhD thesis on Legal Sciences, Yekaterinburg, 2013; Teplova D.O. Criminological characteristics and prevention of organized fraudulent activities: Abstract of the PhD thesis on Legal Sciences. M., 2014 and others.

8 See: Zorin A.V. Political crime: criminological analysis. Abstract of PhD thesis on Legal Sciences. SPb, 2013. P.10.

9 See Astashov S.V. Falsification of evidence in a civil case (part 1 and 3 of Article 303 of the RF Criminal Code): problems of the criminal law qualification. Abstract of PhD thesis on Legal Sciences. M., 2013. P. 3.

10 Subsequently property is also taken over.

11 It is reasonable to accept a proposal to include in the RF Criminal Code a special article providing for liability for seizure of control. See Sokolov I.A.: State and development of a criminal-legal mechanism for combating the illegal seizure of legal persons (raids). PhD thesis on Legal Sciences. M., 2014. P. 11. The rule on countering raids is provided for in Art.249 of the Criminal Code of Kazakhstan.

12 See e.g.: http://parkoffka.ru/index.php?itemid=1559 - accessed date 03.05.2015).

13 See: The deadly spare part. Rossiyskaya Gazeta, 10.29.2010 - http://www.rg.ru/2010/10/29/avia.html - accessed date 03.05.2015

14 See http://www.forumavia.ru/forum/1/9/682833613042621686311249486419_1.shtml?topiccount=1 — accessed date 03.05.2015; http://www.businesspress.ru/newspaper/article mId 34 aId 422966.html - accessed date 03.05.2015.

15 This rule is the same as in p.9 of the Regulation of the Plenum of the Supreme Court of the Russian Federation dated December 27, 2007 No. 51 "On judicial practice in cases of fraud and embezzlement".

16 In practice, there is probably a dispute concerning the mandatory presence of a large scale in the classification of the offense under P. 2 and 3 of Art.238.1 of the RF Criminal Code. It seems that the presence of this feature in the imputation of qualified and highly qualified element of crime is not required. Otherwise it turns out that upon the occurrence of more serious consequences the actions will not form the element of crime, which is contrary to the principle of justice and will violate a common sense.

\section{References}

Astashov S.V. Falsifikatsiya dokozatelstv po grahdanskomu delu (chasti 1 i 3 statyi 303 UK RF): problemy ugolovno-peavovoy kvalifikatsii. Falsification of evidence in a civil case (part 1 and 3 of Article 303 of the RF Criminal Code): problems of the criminal law qualification. Abstract of $\mathrm{PhD}$ thesis on Legal Sciences. M., 2013. P. 3.

Bondar A.V. Moshennichestvo kak vid prestupnogo posyagatelstva protiv sobstvennosti $i$ osobennosti ego proyavleniya $v$ sfere bankovskoi deyatelnosti: ugolovno-pravovoy aspekt. Fraud as a form of criminal assault against property and features of its manifestation in the field of banking activities: Criminal-legal aspect: PhD thesis on Legal Sciences. Krasnoyarsk, 2003.

Falsifikatsii $v$ nauchnoy deyatelnosti. Falsification in science. Siberian skeptical observer paranormality. http://ssop.kspu.ru/falsifik.htm - Accessed date 02/20/2015.

Krasikova A.A. Priobreteniye prava na chuzhoe imushchestvo $i$ khishcheniye chuzhogo imushchestva putem obmana ili zloupotrebleniya doveriyem. Acquisition of property of another and 
theft of property of another by fraud or abuse of trust. PhD thesis on Legal Sciences, Yekaterinburg, 2013.

Kudryavtsev V.N. Obiektivnaya storona prestupleniya. Objective aspect of crime. M., 1960.

Malinin V.B., Parfenov A.F. Obiektivnaya storona prestupleniya. Objective aspect of crime. SPb: Publishing house of the Institute of Law (St. Petersburg). 2004.

Mikhailov N.F. Sposob soversheniya prestupleniya i ego ugolovno-pravovoye zncheniye. Method of committing a crime and its criminal-legal value. PhD thesis on Legal Sciences. M., 2007.

Osokin R.B. Ugolovno-pravovaya kharakteristika sposobov soversheniya moshennichestva. Criminal-legal characteristics of methods of committing fraud: $\mathrm{PhD}$ thesis on Legal Sciences. M., 2004.

Shilovsky S.V. Sposob soversheniya prestupleniya kak priznak ugolovno-nakazuemogo deyaniya $i$ differentsiruyushcheye sredstvo. Method of committing a crime as an indication of the criminal offense and differentiating means. PhD thesis on Legal Sciences. Arkhangelsk, 2014.

Smertelnaya zapchast. The deadly spare part. Rossiyskaya Gazeta, 10.29.2010 - http://www. rg.ru/2010/10/29/avia.html - accessed date 03.05.2015).

Sokolov I.A. Sostoyaniye i razvitiye ugolovno-pravovogo mekhanizma protivodeistviya nezakonnomu zakhvatu yuridicheskikh lits (reiderstvu). State and development of a criminal-legal mechanism for combating the illegal seizure of legal persons (raids). PhD thesis on Legal Sciences. M., 2014.

Teplova D.O. Kriminologicheskaya kharakteristika i preduprezhdeniye organizovannogo moshennichestva. Criminological characteristics and prevention of organized fraudulent activities: Abstract of the PhD thesis on Legal Sciences. M., 2014.

Tutukov A.Yu. Obman kak sposob soversheniya prestupleniy v sfere ekonomiki: istoricheskiy, zakonodatelniy, teoreticheskiy i pravoprimenitelniy aspekty. Deception as a way of committing crimes in the sphere of economics: historical, legislative, theoretical and law-enforcement aspects. Abstract of the PhD thesis on Legal Sciences. Krasnodar, 2008.

Wertheimer A., Cheney N., Santella T. Falsifikatsiya lekarstvennikh preparatov: problem $i$ perspektivy. Counterfeit Pharmaceuticals: Current Status and Future Projections. Journal of the American Pharmaceutical Association 43 (6): 710-718, 2003. (http://www.provisor.com.ua/ archive/2005/N6/art_32.php - Accessed date 02/20/2015).

Yakubovich O.R. Sposob soversheniya prestupleniya i ego ugolovno-pravovoye znacheniye. Method of committing a crime and its criminal-legal value. $\mathrm{PhD}$ thesis on Legal Sciences. M., 2004.

Zorin A.V. Politicheskaya prestupnost: kriminologicheskiy analiz. Political crime: criminological analysis. Abstract of PhD thesis on Legal Sciences. SPb, 2013. 


\title{
Недооценка общественной опасности обмана в российском уголовном праве
}

\author{
В.Ф. Щепельков \\ Санкт-Петербургский государственньй университет \\ Россия, 199034, Санкт-Петербург, Университетская наб., 7-9
}

В статье исследуется проблема адекватности отражения в действующем российском уголовном законе общественной опасности деяний, сопряженных с введением в заблуждение потерпевших.

Автор приходит к выводам о том, что в УК РФ недооченена общественная опасность обманных действий, в том числе и различного рода фальсификачий: криминологически не обосновано исключениеобманакаквозможного способа совершения некоторых преступлений, что нарушает принципы криминализации деяний, дифференциащии и индивидуализации уголовной ответственности; наличие в УК РФ самостоятельного состава обмана (фальсификачии) само по себе не решает вопроса об уголовно-правовой защите интересов, способом нарушения которых выступает обман; законодательную практику усиления ответственности за дополнительные общественно опасные последствия, неизбежно или с высокой вероятностью наступающие в результате обманных действий, следует признать обоснованной. При ее реализачии целесообразно рассмотреть вопрос о включении признака наступления тяжких последствий в качестве квалифицирующего, как это сделано в отночении составов преступлений, предусмотренных в ст. 285, 286 УК РФ.

Ключевые слова: уголовная ответственность, обман, фальсификация, уголовный закон.

Научная специальность: 12.00.00 - юридические науки. 